Tumor necrosis factor- $\alpha$ (TNF- $\alpha$ ) plays an important role in the pathogenesis of rheumatoid arthritis. The present study was to evaluate the effects of lipopolysaccharide (LPS), phytomitogens and cytodifferentiation agents on cytotoxicity of TNF- $\alpha$ secreted by adherent human mononuclear cells (AMC). TNF- $\alpha$ cytotoxicity in LPS-treated, phytomitogen-treated, and cytodifferentiation agent-treated AMC supernatants were analyzed by the L929 bioassay system. Our results showed that LPS could induce homogeneous TNF- $\alpha$ production by AMC whereas, in addition to TNF- $\alpha$, phytomitogens could also induce other TNFlike factors. Neither methotrexate, retinoic acid nor sodium butyrate can inhibit TNF- $\alpha$ cytotoxicity, while hexamethylene bisacetamide could not only inhibit TNF- $\alpha$ cytotoxicity but also TNF- $\alpha$ inducing ability of LPS to AMC.

Key words: TNF- $\alpha$, L929 bioassay, Adherent human mononuclear cells

\section{Establishment of a consistent L929 bioassay system for TNF- $\alpha$ quantitation to evaluate the effect of lipopolysaccharide, phytomitogens and cytodifferentiation agents on cytotoxicity of TNF- $\alpha$ secreted by adherent human mononuclear cells}

\author{
Ming-Yuh Shiau ${ }^{1}$, Hui-Ling Chiou ${ }^{2}$, Yao-Ling Lee ${ }^{2}$, \\ Tzer-Min Kuo ${ }^{3}$ and Yih-Hsin Chang ${ }^{2, \mathrm{CA}}$
}

${ }^{1}$ Hung Kuang Institute of Technology, ${ }^{2}$ School of Medical Technology, and ${ }^{3}$ Institute of Immunology, Chung Shan Medical University, Taichung 402, Taiwan, Republic of China

\footnotetext{
${ }^{\mathrm{CA}}$ Corresponding Author

Tel: +11 886424730022 , ext. 1716

Fax: +118864 23248171

E-mail: cyh@mercury.csmc.edu.tw
}

\section{Introduction}

Rheumatoid arthritis (RA) is a chronic autoimmune disease with clinical features of inflammation and destruction of joints. The pathogenic mechanism of RA is still unknown. Several inflammatory mediators and cytokines have been identified in the synovial fluid of RA patients. ${ }^{1}$ These mediators play important roles in RA pathogenesis since they can induce the release of tissue-damaging enzymes through cell-cell interaction and result in inflammation and destruction of joints.

Tumor necrosis factor- $\alpha$ (TNF- $\alpha$ ) is a pleiotrophic cytokine secreted mainly by monocytes and macrophages. TNF- $\alpha$ has many overlapping bioactivities with interleukin 1 (IL-1). Some of these bioactivities, such as induction of synovial fibroblast proliferation, ${ }^{2}$ stimulation of fibroblasts and chondrocytes to secrete prostaglandin $\mathrm{E}_{2}\left(\mathrm{PGE}_{2}\right)$ and collagenase, ${ }^{3}$ stimulation of monocytes, endothelial cells and cultured rheumatoid synovial cells to produce IL- $1,{ }^{4}$ and activation of polymorphic multinuclear leukocytes, ${ }^{5}$ were reported to be associated with the inflammation, degeneration and destruction of joints. TNF- $\alpha$ in synovial fluid of RA patients was synthesized by synovial tissue and correlated with their seropositivity of TNF- $\alpha$ and disease activity. ${ }^{6}$ High levels of TNF- $\alpha$ mRNA were detected on rheumatoid synovial membrane. ${ }^{7}$ According to these observations, TNF- $\alpha$ indeed plays a crucial role in RA pathogenesis.

Non-steroid anti-inflammatory drugs, penicillamine, azathioprine and cyclophosphamide are usually prescribed for RA treatment; however, these effective medications can lead to adverse side effects. Several studies have demonstrated that a low dose of methotrexate (MTX) was an effective medication in RA intervention with very limited toxicity. ${ }^{8}$ The antiinflammatory capacity of MTX was postulated to be contributed to effective RA treatment. MTX can inhibit not only the synthesis of immunoglobulin M-rheumatoid factor, but the regeneration of methionine to block the synthesis of two important mediators in cellular immune responses: S-adenosylmethionine (SAM) and polyamine. ${ }^{9}$ However, the exact mechanism of MTX to inhibit RA progress remained unclear. Segal et al. has reported that MTX can inhibit neither the synthesis nor secretion of IL-1 both in in vivo and in vitro systems. ${ }^{10}$ Our present study focused on the 
elucidation of MTX effects on the cytotoxicity ofTNF- $\alpha$ secreted by adherent mononuclear cells (AMC). In addition, our study was the first to systemically analyze and demonstrate the effect of various cytodifferentiation agents that drive HL-60 cells differentiation, such as retinoic acid $(\mathrm{Ra})$, sodium butyrate (SB), and hexamethylene bisacetamide (HMBA), on the cytotoxicity of TNF- $\alpha$ secreted by AMC.

The selection of a simple and rapid bioassay with characteristics of high sensitivity and good reproducibility is important for the analysis of TNF- $\alpha$ cytotoxicity. According to the literature, the standard error of the sample mean (SEM) in the standard L929 bioassay system for TNF- $\alpha$ quantitation was reported to range from 5 to $15 \%$. The average SEM of the L929 cytotoxicity bioassay system established in the present study could be reduced to be less than $5 \%$ (on average, $2-3 \%$ ) with our modification. Therefore, our modified L929 bioassay system was rather consistent and would be of benefit to the analysis or quantitation of TNF- $\alpha$ cytotoxicity.

\section{Materials and methods}

\section{AMC isolation}

Peripheral blood mononuclear cells (PBMC) were isolated by Ficoll-Hypaque gradient centrifugation as described previously. Briefly, $30 \mathrm{ml}$ of fresh peripheral blood was gently added onto the top of $24 \mathrm{ml}$ of Ficoll-Hypaque solution. Buffy coat was cautiously collected after centrifugation at $450 \times g$ for $30 \mathrm{~min}$ at $20^{\circ} \mathrm{C}$ and washed three times with Hank's balanced salt solution (HBSS). Ten milliliters of PBMC $\left(4 \times 10^{6}\right.$ cells $/ \mathrm{ml}$ ) was incubated at $37^{\circ} \mathrm{C}$ for $1.5-2 \mathrm{~h}$ in a $100 \mathrm{~mm}$ cell culture plate and washed vigorously (shaking at 150 r.p.m. for $2 \mathrm{~min}$ ) three times with HBSS. Ice-cold complete RPMI-1640 medium (RPMI1640 with $10 \%$ fetal bovine serum, $2 \mathrm{mM}$ of L-glutamine, $100 \mathrm{U} / \mathrm{ml}$ of penicillin and $10 \mu \mathrm{g} / \mathrm{ml}$ of streptomycin) was added to the cell, incubated for 30 min on ice, and AMC were collected by rubber policeman. Cell density was adjusted to $5 \times 10^{5}$ cells/ $\mathrm{ml}$ using complete RPMI-1640 medium. Cell survival rate and the percentage of AMC were determined as $>$ $98 \%$ and $>94 \%$ by trypan blue exclusion test and nonspecific esterase stain, respectively.

\section{AMC treatment}

One milliliter of AMC $\left(5 \times 10^{5}\right.$ cells $\left./ \mathrm{ml}\right)$ was cultured in each well of a 24-well tissue culture plate and incubated at $37^{\circ} \mathrm{C}$ for $1 \mathrm{~h}$. The medium was cautiously discarded after the AMC had adhered to the culture plate. TNF- $\alpha$ secretion of AMC cells was analyzed by adding $1 \mathrm{ml}$ of RPMI-1640 containing various concentrations of phytomitogens and cytodifferentiation agents, respectively, in the presence or absence of lipopolysaccharide (LPS) activation at $37^{\circ} \mathrm{C}$ (summarized in Table 1). Culture medium was collected after desired intervals, centrifuged at $500 \times g$ for $5 \mathrm{~min}$ at $4^{\circ} \mathrm{C}$ and cell-free supernatants were aliquotted and

Table 1. TNF-like cytotoxicity in AMC supernatants stimulated by various agents

\begin{tabular}{|c|c|c|c|c|}
\hline \multicolumn{2}{|c|}{ Inducing agents } & $\begin{array}{c}\text { Absorbance } \\
(570 \mathrm{~nm}-650 \mathrm{~nm}) \\
(\mathrm{mean} \pm \mathrm{SEM})\end{array}$ & $\begin{array}{l}\text { TNF-like \% } \\
\text { cytotoxicity } \\
\text { of L929 cells }\end{array}$ & $\begin{array}{l}\text { Cytotoxic } \\
\text { activity } \\
(\mathrm{U} / \mathrm{ml})^{*}\end{array}$ \\
\hline \multicolumn{2}{|c|}{ None (medium control) } & $654 \pm 14.8$ & 2.36 & $<1.0$ \\
\hline LPS & $0.02 \mu \mathrm{g} / \mathrm{ml}$ & $345 \pm 14.8$ & 73.50 & 55.6 \\
\hline PMA & $\begin{array}{l}200 \mathrm{nM} \\
400 \mathrm{nM}\end{array}$ & $\begin{array}{l}503 \pm 25.3 \\
491 \pm 33.5\end{array}$ & $\begin{array}{l}37.10 \\
39.86\end{array}$ & $\begin{array}{l}5.8 \\
6.1\end{array}$ \\
\hline PHA & $\begin{array}{r}5 \mu \mathrm{g} / \mathrm{ml} \\
10 \mu \mathrm{g} / \mathrm{ml}\end{array}$ & $\begin{array}{l}403 \pm 22.6 \\
394 \pm 18.7\end{array}$ & $\begin{array}{l}60.14 \\
62.22\end{array}$ & $\begin{array}{l}17.2 \\
20.5\end{array}$ \\
\hline PWM & $\begin{array}{l}2 \mu \mathrm{g} / \mathrm{ml} \\
5 \mu \mathrm{g} / \mathrm{ml}\end{array}$ & $\begin{array}{l}388 \pm 10.4 \\
371 \pm 7.2\end{array}$ & $\begin{array}{l}63.59 \\
67.51\end{array}$ & $\begin{array}{l}22.8 \\
28.3\end{array}$ \\
\hline ConA & $\begin{array}{c}5 \mu \mathrm{g} / \mathrm{ml} \\
10 \mu \mathrm{g} / \mathrm{ml}\end{array}$ & $\begin{array}{l}335 \pm 9.8 \\
331 \pm 3.5\end{array}$ & $\begin{array}{l}75.80 \\
76.72\end{array}$ & $\begin{array}{l}58.3 \\
61.1\end{array}$ \\
\hline MTX & $\begin{array}{l}0.5 \mu \mathrm{g} / \mathrm{ml} \\
1.0 \mu \mathrm{g} / \mathrm{ml} \\
2.0 \mu \mathrm{g} / \mathrm{ml} \\
4.0 \mu \mathrm{g} / \mathrm{ml}\end{array}$ & $\begin{array}{l}653 \pm 11.3 \\
646 \pm 10.6 \\
666 \pm 21.9 \\
647 \pm 19.1\end{array}$ & $\begin{array}{l}2.53 \\
4.14 \\
0.46 \\
3.91\end{array}$ & $\begin{array}{l}<1.0 \\
<1.0 \\
<1.0 \\
<1.2\end{array}$ \\
\hline $\mathrm{Ra}$ & $\begin{array}{l}1 \mu \mathrm{M} \\
5 \mu \mathrm{M}\end{array}$ & $\begin{array}{l}628 \pm 7.8 \\
627 \pm 2.1\end{array}$ & $\begin{array}{l}8.29 \\
8.52\end{array}$ & $\begin{array}{l}<1.2 \\
<1.2\end{array}$ \\
\hline SB & $\begin{array}{l}100 \mu \mathrm{g} / \mathrm{ml} \\
250 \mu \mathrm{g} / \mathrm{ml}\end{array}$ & $\begin{array}{l}637 \pm 5.1 \\
642 \pm 11.2\end{array}$ & $\begin{array}{l}6.22 \\
5.06\end{array}$ & $\begin{array}{l}<1.1 \\
<1.0\end{array}$ \\
\hline HMBA & $\begin{array}{r}5 \mathrm{mM} \\
10 \mathrm{mM}\end{array}$ & $\begin{array}{l}642 \pm 3.5 \\
637 \pm 10.6\end{array}$ & $\begin{array}{l}5.06 \\
6.22\end{array}$ & $\begin{array}{l}<1.0 \\
<1.0\end{array}$ \\
\hline
\end{tabular}

* One unit was defined as the amount of TNF- $\alpha$ required to kill $50 \%$ of L929 target cells. 
stored at $-80^{\circ} \mathrm{C}$ until use. The survival rate of adherent cell was determined to be $>95 \%$ after the culture medium was collected. In investigating the dose effect of MTX and cytodifferentiation agents on the TNF- $\alpha$ secretion by AMC, $5 \times 10^{5}$ cells/well of AMC cells were incubated with $1 \mathrm{ml}$ of LPS $(0.02 \mu \mathrm{g} / \mathrm{ml})$ containing RPMI-1640 with MTX ( $1 \mathrm{ng} / \mathrm{ml}-1 \mathrm{mg} / \mathrm{ml})$, $\mathrm{Ra}(0.5-80 \mu \mathrm{M})$ or $\mathrm{SB}(5-800 \mathrm{mM})$, respectively, at $37^{\circ} \mathrm{C}$. For ruling out the possibility that there might be some mutual interaction between MTX or cytodifferentiation agents and LPS, LPS-containing medium was removed after $1 \mathrm{~h}$ of pulse and AMC was washed three times with serum-free medium before treatment with MTX or cytodifferentiation agents. Culture supernatants were collected and stored as already described.

\section{Cell culture}

Murine L929 fibroblasts and human HEp-2 cells were incubated in RPMI-1640 complete medium (RPMI-1640 with $10 \%$ fetal bovine serum, $2 \mathrm{mM}$ of L-glutamine, $100 \mathrm{U} / \mathrm{ml}$ of penicillin and $100 \mu \mathrm{g} / \mathrm{ml}$ of streptomycin) and DMEM medium, respectively, at $37^{\circ} \mathrm{C}$.

\section{Evaluation of cellular susceptibility to recombinant human TNF- $\alpha$}

Confluent monolayer murine L929 fibroblasts were trypsinized and resuspended to $2 \times 10^{4}$ cells $/ \mathrm{ml}$ with RPMI-1640. One hundred microliters of cell suspension was seeded to each well of a 96-well tissue culture plate. The medium was discarded after overnight culture and replaced by RPMI-1640 containing various concentrations of recombinant human TNF- $\alpha$ (rhTNF- $\alpha$ ) and $1 \mu \mathrm{g} / \mathrm{ml}$ of actinomycin D. MTT (3-[4,5-dimethylthiazol-2-yl]-2,5-diphenyl tetrazolium bromide, tetrazolium salt) assay was conducted after $16-20 \mathrm{~h}$ of culture at $37^{\circ} \mathrm{C}$. The sensitivity of HEp-2 to rhTNF- $\alpha$ was analyzed using similar procedure without actinomycin D exposure.

\section{L929 cytotoxicity bioassay}

L929 cytotoxicity was analyzed by modifying the methods form Baarsch et al. ${ }^{11}$ and Galloway et al. ${ }^{12}$ The flowchart of our modified version is summarized in Fig. 1. Briefly, $2 \times 10^{4}$ cells/well of L929 cells in a 96-well tissue culture plate were overnight cultured at $37^{\circ} \mathrm{C}$. The medium was replaced by $100 \mu 1$ of AMC cell-free supernatants collected as already described. After L929 cells were exposed in the supernatants for $20 \mathrm{~h}, 20 \mu \mathrm{l}$ of $2.5 \mathrm{ng} / \mathrm{ml}$ MTT was added into each well of AMC supernatanttreated L929 cells. After $4 \mathrm{~h}$ of incubation at $37^{\circ} \mathrm{C}$, the microplate was centrifuged at $500 \times g, 4^{\circ} \mathrm{C}$ for $10 \mathrm{~min}$. Then the supernatants in the wells were
FIG. 1. Flowchart of the modified L929 cytotoxic bioassay system for TNF- $\alpha$ quantitation.

carefully discarded and $100 \mu \mathrm{l} /$ well of dimethylsulfoxide (DMSO) was added into the plate to dissolve Formazan crystals for $10 \mathrm{~min}$. The absorbance was read and recorded under $570 \mathrm{~nm}$, with reference absorbance under $650 \mathrm{~nm}$. Results were represented as the absorbance at $570 \mathrm{~nm}$ subtracted from that of $650 \mathrm{~nm}$ or as the percentage of L929 cytotoxicity. The percentage of L929 cytotoxicity was calculated by following formula:

$$
\begin{aligned}
& \text { Absorbance of } 100 \% \text { viable } \\
& \text { cell control wells - } \\
& \% \text { cytotoxicity }=\frac{\text { absorbance of test wells }}{\text { Absorbance of } 100 \% \text { viable }} \times 100 \\
& \text { cell control wells }
\end{aligned}
$$

The mean \pm SEM of the percentage of L929 cytotoxicity was calculated by data obtained from three to eight wells. 


\section{Neutralization test}

The neutralization test was conducted according to Galloway et al. ${ }^{12}$ Briefly, AMC supernatants were diluted by RPMI-1640 and co-incubated with equal volume of various concentration of TNF- $\alpha$ monoclonal antibody solution containing $2 \mu \mathrm{g} / \mathrm{ml}$ actinomycin D at room temperature for $2 \mathrm{~h}$. One hundred microliters of the diluted supernatant was added to each well of a 96-well tissue culture plate and the L929 cytotoxicity test was conducted.

\section{Statistical analysis}

The statistical significance of the mean \pm SEM was analyzed by Student's $t$-test.

\section{Results}

The present study focused on using a modified L929 cytotoxicity bioassay system for TNF- $\alpha$ quantitation to analyze the effect of MTX and cytodifferentiation agents, such as $\mathrm{Ra}, \mathrm{SB}$, and HMBA, on the cytotoxicity of TNF- $\alpha$ secreted by AMC. In addition, the effect of LPS, $\quad 4 \beta$-phorbol-12 $\beta$-myristate-13 $\alpha$-acetate (PMA), phytohemagglutinin (PHA), pokeweed mitogen (PWM) and concanavalin A (ConA) on cytotoxicity of TNF- $\alpha$ secreted by AMC were also investigated.

In traditional MTT cytotoxicity assay, the tetrazolium salt will be reduced to produce Formazan crystals by mitochondrial succinate dehydrogenase in viable cells. TNF- $\alpha$ cytotoxicity could be indirectly examined by enzyme-linked immunosorbent assay reader after the Formazan crystals were completely dissolved by solvents. Therefore, whether the crystals could be completely dissolved would significantly affect the result of cytotoxicity test. Among various solvents reported in the literature, $10 \%$ sodium dodecyl sulfate (SDS)-0.01 N HCl, 10\% SDS-50\% isopropanol, 20\% SDS-50\% dimethylformamide, 10\%
SDS-50\% DMSO, and DMSO alone were relatively better solvents for Formazan crystal-dissolving purpose (Table 2). In terms of the incubation time and mixing requirement, DMSO was the most convenient solvent. Therefore, we chose DMSO as the crystaldissolving solution in our study.

HEp-2 and L929 are cell lines that have been commonly used for the analysis of TNF- $\alpha$ cytotoxicity. We first tested the susceptibility of those two cell lines to rhTNF- $\alpha$ for establishing the bioassay system. The $50 \%$ inhibition concentration $\left(\mathrm{IC}_{50}\right)$ of TNF- $\alpha$ to the HEp-2 cell was determined to be higher than $10 \mathrm{ng} / \mathrm{ml}$ (Fig. 2A), while that of the L929 cell was approximately $0.18 \mathrm{ng} / \mathrm{ml}$ (Fig. 2B). Therefore, we chose L929 cells as target cells in our assay system since L929 cells exhibited relatively high sensitivity to TNF- $\alpha$ and might perform better precision in the evaluation of TNF- $\alpha$ cytotoxicity.

AMC was cultured in complete RPMI-1640 medium containing various agents respectively listed in Table 1. TNF- $\alpha$ cytotoxic activity of the AMC cell-free culture supernatants under the exposure of various agents was analyzed by L929 bioassay system. The results are summarized in Table 1. MTX and cytodifferentiation agents showed no stimulatory capacity on AMC to produce TNF- $\alpha$ or TNF-like factors ( $<10 \%$ of TNF-like cytotoxicity to the L929 cell). Among the agents tested in the study, ConA and PMA were relatively the strongest and weakest that could induce the TNF-like cytotoxicity, respectively.

Under continuous LPS exposure, AMC could be immediately activated and the TNF- $\alpha$ cytotoxicity was rapidly increased and reached a plateau within $10 \mathrm{~h}$. Therefore, high TNF- $\alpha$ cytotoxicity could be detected in AMC culture supernatants by L929 cytotoxicity assay (Fig. 3A). When AMC was temporarily pulsed by LPS for only $1 \mathrm{~h}$, residual TNF- $\alpha$ cytotoxicity could be consistently detected after $36 \mathrm{~h}$ of LPS removal; however, the cytotoxicity would be significantly

Table 2. Comparison of dissolving capacity of various solvents to Formazan crystals

\begin{tabular}{|c|c|c|c|c|c|}
\hline Solvent & $\begin{array}{c}\text { Formazan } \\
\text { crystal } \\
\text { solubility }\end{array}$ & Mixing & $\begin{array}{l}\text { Incubation } \\
\text { time }\end{array}$ & $\begin{array}{l}\text { Dye-grain } \\
\text { and/or ppt }\end{array}$ & $\mathrm{pH}$ \\
\hline Isopropanol & + & - & $10 \mathrm{~min}$ & ++ & 4 \\
\hline Methyl alcohol & + & - & $10 \mathrm{~min}$ & + & ND \\
\hline Ethyl alcohol & + & - & $10 \mathrm{~min}$ & + & ND \\
\hline 1-Butanol & \pm & - & $30 \mathrm{~min}$ & ++ & ND \\
\hline 2-Butanol & \pm & - & $30 \mathrm{~min}$ & +++ & ND \\
\hline Acid-isopropanol (0.04 N HCl) & + & + & $1-2 \mathrm{~h} / 16 \mathrm{~h}$ & $++/-$ & $2-3$ \\
\hline $10 \%$ SDS in $0.01 \mathrm{~N} \mathrm{HCl}$ & ++ & - & $1 \mathrm{~h} / 16 \mathrm{~h}$ & $\pm /-$ & $3-4$ \\
\hline $10 \%$ SDS in $0.1 \mathrm{~N} \mathrm{HCl}$ & $+++^{*}$ & - & $10 \mathrm{~min}$ & - & $1-2$ \\
\hline $10 \%$ SDS-50\% isopropanol & ++ & $+/-$ & $2 \mathrm{~h} / 16 \mathrm{~h}$ & - & $6-7$ \\
\hline $20 \%$ SDS $-50 \%$ dimethylformamide & +++ & $+/-$ & $1-2 \mathrm{~h} / 16 \mathrm{~h}$ & - & $4-5$ \\
\hline Mineral oil & + & - & $>16 \mathrm{~h}$ & - & ND \\
\hline $10 \%$ SDS-50\% DMSO & +++ & - & $16 \mathrm{~h}$ & - & $7-8$ \\
\hline
\end{tabular}

ppt, Precipitate. ND, Not determined.

* Formazan crystals were oxidized in strongly acidic solvent and turned yellow instead of purple. 
FIG. 2. (A) Dose-response curve of human HEp-2 cells in response to rhTNF- $\alpha$. Various concentrations of rhTNF- $\alpha$ were diluted with complete RPMI-1640 medium. Details are described in Materials and methods. Positive control wells containing $200 \mathrm{ng} / \mathrm{ml}$ of rhTNF- $\alpha$ were used as blank. The IC $\mathrm{I}_{50}$ of rhTNF- $\alpha$ to HEp- 2 cells was estimated to be more than $10 \mathrm{ng} / \mathrm{ml}$. (B) Dose-response curve of murine L929 fibroblasts in response to rhTNF- $\alpha$. Details of the L929 bioassay and MTT stain are described in Materials and methods. The $\mathrm{IC}_{50}$ of rhTNF- $\alpha$ to $L 929$ cells was estimated to be $0.18 \mathrm{ng} / \mathrm{ml}$.

decreased thereafter (Fig. 3B). For identifying whether LPS could induce AMC to secrete other factors that exhibited TNF-like cytotoxicity, various concentrations of anti-TNF- $\alpha$ monoclonal antibody $(5-100 \mathrm{ng} / \mathrm{ml})$ was added into the cell-free supernatants to neutralize TNF- $\alpha$ cytotoxicity, and the residual TNF-like cytotoxicity of the AMC supernatant was subsequently analyzed. Fig. 4 shows that the TNF-like cytotoxicity would be completely inhibited when the concentration of anti-TNF- $\alpha$ monoclonal antibody was higher than $20 \mathrm{ng} / \mathrm{ml}$. The results demonstrated that TNF-like cytotoxicity induced by LPS was mainly contributed by homogeneous TNF- $\alpha$ (Fig. 4 and Table 3). However, in addition to TNF- $\alpha$, the TNF-like cytotoxicity induced by other mitogens, such as PHA, PMA, and ConA, seemed to be caused by factors other than TNF- $\alpha$ since there was residual TNF-like cytotoxic activity after anti-TNF- $\alpha$ monoclonal antibody neutralization (Table 3).

We next analyzed the effect of MTX and cytodifferentiation agents on cytotoxicity of TNF- $\alpha$ secreted by LPS-activated AMC. AMC were activated with $0.02 \mu \mathrm{g} / \mathrm{ml}$ LPS in the presence of MTX at various concentrations ( $1 \mathrm{ng} / \mathrm{ml}-1 \mathrm{mg} / \mathrm{ml})$, TNF- $\alpha$ cytotoxicity of the culture supernatants was analyzed after overnight incubation. Our results showed that MTX, either in the condition of continuous $(p>0.1$; Fig. 5A) or temporary $(p>0.1$; Fig. $5 \mathrm{~B})$ exposure, had no inhibitory capacity to cytotoxicity of TNF- $\alpha$ secreted by AMC. The cytotoxicity of rhTNF- $\alpha$ activity would neither be affected when rhTNF- $\alpha$ was incubated overnight with various concentration of MTX (data not shown). For ruling out the possibility that lack of 
MTX inhibition to cytotoxicity of TNF- $\alpha$ secreted by AMC was due to mutual physical or chemical interaction between LPS and MTX, TNF- $\alpha$ cytotoxicity in the supernatants was analyzed after AMC was first pulsed with LPS for $1 \mathrm{~h}$ and subsequently treated with MTX for 2 or $16 \mathrm{~h}$ after LPS removal. The results showed that MTX remained no inhibition capacity to TNF- $\alpha$ cytotoxicity (Fig. 6A,B).

The residual mitogens and cytodifferentiation agents in the AMC culture supernatants might cause cytotoxic effect that would reinforce the TNF- $\alpha$ cytotoxicity. Therefore, we further investigated the L929 cytotoxicity caused by each agent for ruling out this possibility. These agents were proved not to exhibit cytotoxicity to L929 cells under the concentration of AMC treatment $(<0.5 \mathrm{U} / \mathrm{ml}$; data not shown). The cytotoxicity of rhTNF- $\alpha$ was also not inhibited by those agents when we incubated L929 cells in the presence of each agent and rhTNF- $\alpha$. In addition, $1 \mathrm{ng} / \mathrm{ml}$ to $2 \mu \mathrm{g} / \mathrm{ml}$ of anti-TNF- $\alpha$ monoclonal antibody had no L929 cytotoxicity either (data not shown). Only high dosage of HMBA (> $40 \mathrm{mM})$ showed substantially low cytotoxicity $(1-1.5 \mathrm{U} / \mathrm{ml})$ among cytodifferentiation agents (data not shown).

Fig. 7 demonstrates the results of the effect of $\mathrm{Ra}$, SB, and HMBA to cytotoxicity of TNF- $\alpha$ secreted by AMC. The data showed that only HMBA (0.5-80 mM) had significant inhibition capacity to cytotoxicity of TNF- $\alpha$ secreted by LPS-activated AMC, whereas Ra $(0.5-80 \mu \mathrm{M})$ and SB $(5-400 \mu \mathrm{g} / \mathrm{ml})$ showed no inhibition $(p>0.05)$.

For ruling out the possibility of mutual interaction between LPS and cytodifferentiation agents and further investigating the correlation between cytodifferentiation agents and TNF- $\alpha$ cytotoxicity, TNF- $\alpha$ activity was analyzed after AMC was first pulsed by LPS

FIG. 3. (A) Time course of TNF cytotoxicity produced by AMC cultured in complete RPMI- 1640 containing $0.02 \mu \mathrm{g} / \mathrm{ml}$ of LPS. Crude supernatants were harvested at the time indicated and TNF cytotoxicity in $10 \times$ diluted cell-free supernatants was analyzed. (B) Time course of TNF cytotoxicity produced by AMC activated under $1 \mathrm{~h}$ of $0.02 \mu \mathrm{g} / \mathrm{ml}$ LPS stimulation. Crude supernatants were harvested at the time indicated and TNF cytotoxicity in $4 \times$ diluted cell-free supernatants was assayed. 
FIG. 4. Neutralization curve of TNF- $\alpha$ cytotoxicity in LPS-stimulated AMC supernatants by anti-TNF- $\alpha$ monoclonal antibody. TNF- $\alpha$ cytotoxicity in $10 \times$ diluted AMC supernatants containing final concentrations of $5,20,50$ or $100 \mathrm{ng} / \mathrm{ml}$ anti-TNF- $\alpha$ monoclonal antibody was assayed. Details are described in Materials and methods.

for $1 \mathrm{~h}$ and subsequently incubated with cytodifferentiation agents. Fig. 8 shows that only high concentrations of HMBA $(>10 \mathrm{mM})$ and SB $(>400 \mu \mathrm{g} / \mathrm{ml})$ exhibited significant and slightly inhibitory capacity

Table 3. Residual TNF-like cytotoxicity in AMC supernatants with anti-TNF- $\alpha$ monoclonal antibody neutralization

\begin{tabular}{|c|c|c|c|}
\hline \multicolumn{2}{|c|}{ Inducing agent } & $\begin{array}{c}\text { Cytotoxicity } \\
\text { activity } \\
(\mathrm{U} / \mathrm{ml})\end{array}$ & $\begin{array}{c}\text { Residual cytotoxic } \\
\text { activity }(\mathrm{U} / \mathrm{ml}) \\
\text { remaining after } \\
\text { anti-TNF- } \alpha \\
\text { neutralization }\end{array}$ \\
\hline \multicolumn{2}{|c|}{$\begin{array}{l}\text { None (medium } \\
\text { control) }\end{array}$} & $<1.0$ & $<0.5$ \\
\hline LPS & $0.02 \mu \mathrm{g} / \mathrm{ml}$ & 55.6 & $<0.5$ \\
\hline PMA & $\begin{array}{l}200 \mathrm{nM} \\
400 \mathrm{nM}\end{array}$ & $\begin{array}{l}5.8 \\
6.1\end{array}$ & $\begin{array}{l}1.8 \\
1.9\end{array}$ \\
\hline PHA & $\begin{array}{r}5 \mu \mathrm{g} / \mathrm{ml} \\
10 \mu \mathrm{g} / \mathrm{ml}\end{array}$ & $\begin{array}{l}17.2 \\
20.5\end{array}$ & $\begin{array}{l}4.1 \\
5.1\end{array}$ \\
\hline PWM & $\begin{array}{l}2 \mu \mathrm{g} / \mathrm{ml} \\
5 \mu \mathrm{g} / \mathrm{ml}\end{array}$ & $\begin{array}{l}22.8 \\
28.3\end{array}$ & $\begin{array}{l}<1.0 \\
<1.0\end{array}$ \\
\hline ConA & $\begin{array}{r}5 \mu \mathrm{g} / \mathrm{ml} \\
10 \mu \mathrm{g} / \mathrm{ml}\end{array}$ & $\begin{array}{l}58.3 \\
61.1\end{array}$ & $\begin{array}{l}1.6 \\
1.7\end{array}$ \\
\hline MTX & $\begin{array}{l}0.5 \mu \mathrm{g} / \mathrm{ml} \\
1.0 \mu \mathrm{g} / \mathrm{ml} \\
2.0 \mu \mathrm{g} / \mathrm{ml} \\
4.0 \mu \mathrm{g} / \mathrm{ml}\end{array}$ & $\begin{array}{l}<1.0 \\
<1.0 \\
<1.0 \\
<1.0\end{array}$ & $\begin{array}{l}<0.5 \\
<0.5 \\
<0.5 \\
<0.5\end{array}$ \\
\hline $\mathrm{Ra}$ & $\begin{array}{l}1 \mu \mathrm{M} \\
5 \mu \mathrm{M}\end{array}$ & $\begin{array}{l}<1.2 \\
<1.2\end{array}$ & $\begin{array}{l}<0.5 \\
<0.5\end{array}$ \\
\hline SB & $\begin{array}{l}100 \mu \mathrm{g} / \mathrm{ml} \\
250 \mu \mathrm{g} / \mathrm{ml}\end{array}$ & $\begin{array}{l}<1.0 \\
<1.0\end{array}$ & $\begin{array}{l}<0.5 \\
<0.5\end{array}$ \\
\hline HMBA & $\begin{array}{r}5 \mathrm{mM} \\
10 \mathrm{mM}\end{array}$ & $\begin{array}{l}<1.0 \\
<1.0\end{array}$ & $\begin{array}{l}<0.5 \\
<0.5\end{array}$ \\
\hline
\end{tabular}

to cytotoxicity of TNF- $\alpha$ secreted by LPS-activated AMC. Similar results were obtained when the HMBA was removed after overnight incubation with LPSactivated AMC to allow further TNF- $\alpha$ secretion (data not shown).

\section{Discussion}

Many cell lines have been used in the analysis of TNF- $\alpha$ cytotoxicity. The $\mathrm{IC}_{50}$ of rhTNF- $\alpha$ (with specific activity $\left.(2-4) \times 10^{8} \mathrm{U} / \mathrm{ml}\right)$ to ME-180, HeLa and MRC-5 cells was approximately $1 \mathrm{ng} / \mathrm{ml}$, and that of U937 cell was about $0.3 \mathrm{mg} / \mathrm{ml}^{12}$ A simple TNF- $\alpha$ bioassay was established using HEp-2 cells as target cells $;{ }^{13}$ however, the $\mathrm{IC}_{50}$ of rhTNF- $\alpha$ to HEp-2 cells was detected to be higher than $10 \mathrm{ng} / \mathrm{ml}$ in this system (Fig. 2A). This result supported the observation that HEp-2 cells showed low sensitivity to TNF$\alpha$. WEHI 1640 subclone 13 cells were reported to be more sensitive to TNF- $\alpha$ than L929 cells, but the cell density was too high and their sensitivity to TNF- $\alpha$ would be decreased or even turned out to be insensitive after multiple subcloning. ${ }^{14}$ The L929 cell line was the most common target cell for the detection of TNF- $\alpha$ cytotoxicity ${ }^{15}$ since the analysis of TNF- $\alpha$ cytotoxicity to L929 would not be affected by rhIL-1 and interferon- $\alpha$. Therefore, we chose L929 as target cells in the analysis of TNF- $\alpha$ cytotoxicity. The chemicals used in our study had no cytotoxic effects to $\mathrm{L} 929$ and the $\mathrm{IC}_{50}$ of rhTNF- $\alpha$ to $\mathrm{L} 929$ cells was only about $0.18 \mathrm{ng} / \mathrm{ml}$ in our study (Fig. 2B).

Conventional analytic methods for cellular growth/ proliferation and survival included calculation of 
FIG. 5. Effect of MTX on TNF- $\alpha$ cytotoxicity. AMC were activated by $0.02 \mu \mathrm{g} / \mathrm{ml}$ LPS in the presence of MTX at various concentrations $(1 \mathrm{ng} / \mathrm{ml}-1 \mathrm{mg} / \mathrm{ml})$. After overnight culture, cell was washed to remove the LPS and MTX, and then subsequently further incubated in the presence $(A)$ or absence (B) of MTX for $24 \mathrm{~h}$ to allow TNF- $\alpha$ secretion. TNF cytotoxicity in $10 \times(A)$ or $5 \times(B)$ diluted supernatants was analyzed.

staining cells by using dyes (such as crystal violet, neutral red, etc.), measurement of ${ }^{51} \mathrm{Cr}$-labeled protein released by lyzed cells, and detection of the incorporation of radioisotope-labeled nucleic acid (such as $\left[{ }^{3} \mathrm{H}\right]$-thymidine or $\left[{ }^{125} \mathrm{I}\right]$-iododeoxyuridine). The MTT colorimetric assay has been widely used since it was developed. The principle of MTT test was the reduction of tetrazolium ring to dark-blue Formazan crystals by mitochondrial succinate dehydrogenase ${ }^{16}$ Cell survival can be evaluated by measuring the absorbance of Formazan crystals dissolved in solution at $570 \mathrm{~nm}$. The number of survival cells and the cytotoxicity of TNF- $\alpha$ is proportional and reciprocally correlated with the absorbance. The SEM of MTT colorimetric assay of TNF- $\alpha$ cytotoxicity on L929 cells was reported to be among 5-15\%. ${ }^{15,17,18}$ But the SEM of MTT test has been reduced to be less than 5\% (on average, $2-3 \%$ ) by our modification. Our modifications of MTT assay were as following (Fig. 1). L929 cells were allowed to be pre-incubated overnight for better stability. The initiative cell density was $2 \times 10^{4}$ cells/well in a 96-well tissue culture plate, and this would become approximately $95 \%$ confluence when harvested. Control of cell number was an important factor that could remain constant TNF- $\alpha$ sensitivity of the target cells. Besides, the removal of culture medium before Formazan crystal dissolution by centrifugation could be of benefit to both the prevention of a pseudopositive result due to phenol red in medium and a significant increase in the dissolution of the Formazan crystal. The results from our modified MTT assay had low SEM and high reproducibility. We expected that this modified L929 bioassay system would be of great potential to be applied in clinical analysis or quantitation of TNF- $\alpha$ cytotoxicity.

The effect of PMA, PHA and ConA to PBMC has been investigated, ${ }^{19}$ and the results indicated that mitogen was a relative stronger inducer of TNF- $\alpha$ secretion on PBMC. Our study investigated the induction ability of LPS and other mitogens, such as PHA, PMA, ConA and PWM, on cytotoxicity of TNF- $\alpha$ secreted by AMC. We found that LPS could induce homologous TNF- $\alpha$ secretion; in addition, its induction ability was higher than that of other mitogens (Table 2). The nature and characteristics of TNF-like factors induced by mitogen-induced AMC await further study to be elucidated.

MTX is an effective chemical in the RA intervention. Nevertheless, its mechanism of action needed further

FIG. 6. Effect of MTX on cytotoxicity of TNF- $\alpha$ secreted by LPS-pulsed AMC. After $1 \mathrm{~h}$ of $0.02 \mu \mathrm{g} / \mathrm{ml}$ of LPS stimulation, $A M C$ were washed and further incubated for $2 \mathrm{~h}(\mathrm{~A})$ or overnight $(B)$ in the presence of MTX at various concentrations $\left(10^{-6}\right.$ to $\left.10^{-2} \mathrm{mg} / \mathrm{ml}\right)$. TNF cytotoxicity in $10 \times$ diluted supernatants was analyzed. 
FIG. 7. Effect of cytodifferentiation agents (HMBA, Ra and SB) on cytotoxicity of TNF- $\alpha$ secreted by AMC. AMC were activated with $0.02 \mu \mathrm{g} / \mathrm{ml}$ of LPS in the presence of cytodifferentiation agents at various concentrations (as summarized in Table 1). After overnight culture, cell-free supernatants were harvested and TNF cytotoxicity in $10 \times$ diluted supernatants was analyzed.

investigation. MTX exhibited anti-inflammatory activity $^{8-10}$ such as inhibition of PMN and monocyte chemotaxis, ${ }^{20}$ inhibition of B-cell and T-cell function, ${ }^{21}$ and indirect inhibition of SAM and polyamine formation through downregulation of dihydrofolate reductase. Segal et al. ${ }^{10}$ demonstrated that MTX could selectively inhibit IL-1 activity rather than its synthesis and secretion. The present study examined the effect

FIG. 8. Effect of cytodifferentiation agents on cytotoxicity of TNF- $\alpha$ secreted by LPS-pulsed AMC. After $1 \mathrm{~h}$ of $0.02 \mu \mathrm{g} / \mathrm{ml}$ LPS stimulation, AMC were washed and further incubated overnight in the presence of cytodifferentiation agents at various concentrations (as summarized in Table 1). TNF cytotoxicity in $5 \times$ diluted supernatants was analyzed. 
of MTX or cytodifferentiation agents on the cytotoxicity of TNF- $\alpha$ secreted by LPS-activated AMC. We found MTX ( $1 \mathrm{ng} / \mathrm{ml}-1 \mathrm{mg} / \mathrm{ml})$ showed no inhibition to TNF- $\alpha$ cytotoxicity (Figs. 5 and 6) whereas HMBA exhibited significant inhibitory effect on cytotoxicity of TNF- $\alpha$ secreted by LPS-activated AMC (Fig. 7). The inhibition of HMBA to cytotoxicity of TNF- $\alpha$ secreted by LPS-activated AMC might be due to the following mechanisms. First of all, HMBA could kill AMC since higher concentrations of HMBA exhibited cytotoxicity to L929 cells. Second, the mutual interaction between HMBA and LPS could block AMC activation by LPS. Third, HMBA could indeed inhibit TNF- $\alpha$ synthesis and secretion. Forth, HMBA can inhibit TNF$\alpha$ cytotoxicity to L929. The first possibility can be ruled out by the trypan blue exclusion test. High concentrations of HMBA ( $>10 \mathrm{mM}$ ) indeed exhibited an inhibitory effect on TNF- $\alpha$ cytotoxicity to L929 (Figs. 7 and 8). HMBA also could partially block AMC activation by LPS (Figs. 7 and 8). However, whether the TNF- $\alpha$ sensitivity of L929 could be decreased by HMBA awaits further study.

On analysis of various cytodifferentiation agents and mitogens, we found HMBA showed inhibitory effect of TNF- $\alpha$ cytotoxicity of L929. However, whether HMBA could inhibit other biological effects of TNF- $\alpha$, such as the stimulation of fibroblast proliferation, induction of $\mathrm{PGE}_{2}$ and collagenase, and be a potential medication for RA treatment requires further investigation. Besides, the activation of $\mathrm{CD}^{+}$ $\mathrm{T}$ cells is suggested as an important factor in RA pathogenesis; ${ }^{22}$ therefore, it would be intriguing to examine whether MTX and HMBA could regulate other RA pathogenesis-related cytokines.

\section{References}

1. Weyand CM. New insights into the pathogenesis of rheumatoid arthritis Rheumatology 2000; 39(Suppl 1): 3-8.

2. Sugarman BJ, Aggarwal BB, Hass PE, Figari IS, Palladino MA Jr, Shepard HM. Recombinant human tumor necrosis factor- $\alpha$ : effects on proliferation of normal and transformed cells in vitro. Science 1985; 230 : 943-945.

3. Dayer JM, Beutler B, Cerami A. Cachectin/tumor necrosis factor stimulates collagenases and prostaglandin E2 production by human synovial cells and dermal fibroblasts. $J$ Exp Med 1985; 162: 2163-2168.

4. Brennan FM, Chantry D, Jackson A, Maini R, Feldmann M. Inhibitory effect of TNF- $\alpha$ antibodies on synovial cell interleukin-1 production in rheumatoid arthritis. Lancet 1989; II: 244-247.

5. Shalaby MR, Aggarwal BB, Rinderknecht E, Svedersky LP, Finkle BS, Palladino MA Jr. Activation of human polymorphonuclear neutrophil functions by interferon- $\gamma$ and tumor necrosis factor. $J$ Immunol 1985 ; 135: 2069-2073

6. Yocum DE, Esparza L, Dubry S, Benjamin JB, Volz R, Scuder P. Characteristics of tumor necrosis factor production in rheumatoid arthritis. Cell Immunol 1989; 122: 131-145.

7. Firestein GS, Alvaro-Gracia JM, Ivaifler NJ. Quantitative analysis of cytokine gene expression in rheumatoid arthritis [abstract]. Clin Res 1989; 37: 586A.

8. Weinblatt ME, Coblyn JS, Fox DA, et al. Efficacy of low-dose methotrexate in rheumatoid arthritis. $N$ Engl J Med 1985; 312: 818-822.

9. Olsen NJ, Callahan LF, Pincus T. Immunologic studies of rheumatoid arthritis patients treated with methotrexate. Arthritis Rbeum 1987; 30: 481-488.

10. Segal R, Mozes E, Yaron M, Tartakovsky B. The effects of methotrexate on the production and activity of interleukin-1. Arthritis Rbeum 1989; 32 $370-377$

11. Baarsch MJ, Wannemuehler MJ, Molitor TW, Murtaugh MP. Detection of tumor necrosis factor $\alpha$ from porcine alveolar macrophages using an L929 fibroblast bioassay. J Immunol Metbods 1991; 140: 15-22.

12. Galloway CJ, Madanat MS, Mitra G. Monoclonal anti-tumor necrosis factor (TNF) antibodies protect mouse and human cells from TNF cytotoxicity. J Immunol Methods 1991; 140: 37-43.

13. Muzes G, Vien CV, Gonzalez-Cabello R, Gergely P, Feher J. Simple assay for tumor necrosis factor using HEp-2 target cells. J Clin Lab Immunol 1989; 30: 41-44.

14. EspevikT, Nissen-Meyer J. A highly sensitive cell line, WEHI 164 clone 13 for measuring cytotoxic factor/tumor necrosis factor from human monocytes. I Immunol Methods 1986; 95: 99-105.

15. Flick DA, Gifford GE. Comparison of in vitro cell cytotoxic assays for tumor necrosis factor. J Immunol Methods 1984; 68: 167-175.

16. Mosmann T. Rapid colorimetric assay for cellular growth and survival: application to proliferation and cytotoxicity assays. J Immunol Methods $1983 ; 65: 55-63$

17. Hay H, Cohen J. Studies on the specificity of the L929 cell bioassay for the measurement of tumor necrosis factor. J Clin Lab Immunol 1989; 29: 151-155.

18. Denizot F, Lang R. Rapid colorimetric assay for cell growth and survival Modifications to the tetrazolium dye procedure giving improved sensitivity and reliability. I Immunol Methods 1986; 89: 271-277.

19. Nedwin GE, Svedersky LP, Bringman TS, Palladino MA Jr, Goeddel DV. Effect of interleukin 2, interferon-gamma and mitogens on the production of tumor necrosis factor $\alpha$ and $\beta . J$ Immunol 1985; 135 1492-1497.

20. O'Callaghan JW, Forrest MJ, Brooks PM. Inhibition of neutrophil chemotaxis in methotrexate treated rheumatoid arthritis patients Rbeumatol Int 1988; 8: 41-45.

21. Olsen NJ, Murray LM. Antiproliferative effects of methotrexate on peripheral blood mononuclear cells. Arthritis Rheum 1989; 32 378-385.

22. Kingsley G, Pitzalis C, Panayi GS. Immunogenetic and cellular immune mechanisms in rheumatoid arthritis: relevance to new therapeutic strategies. Br J Rbeumatol 1990; 29: 58-64.

Received 1 May 2001;

Accepted 28 May 2001 


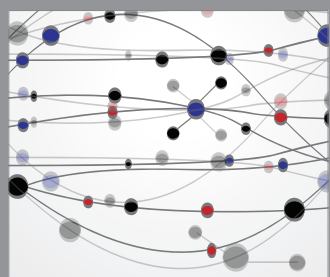

The Scientific World Journal
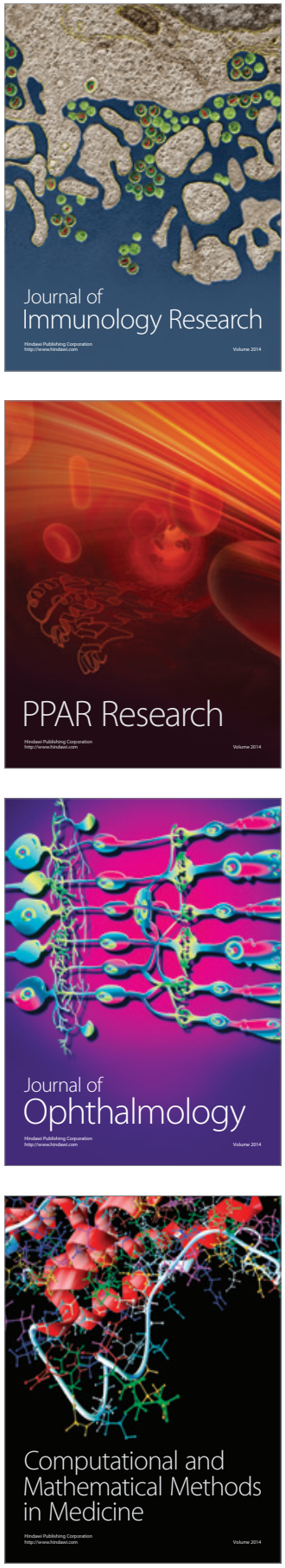

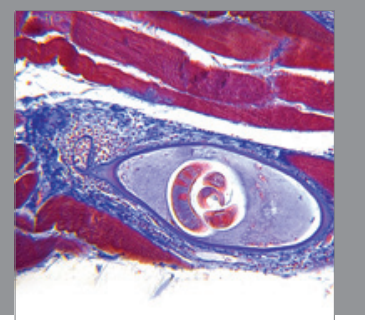

Gastroenterology

Research and Practice
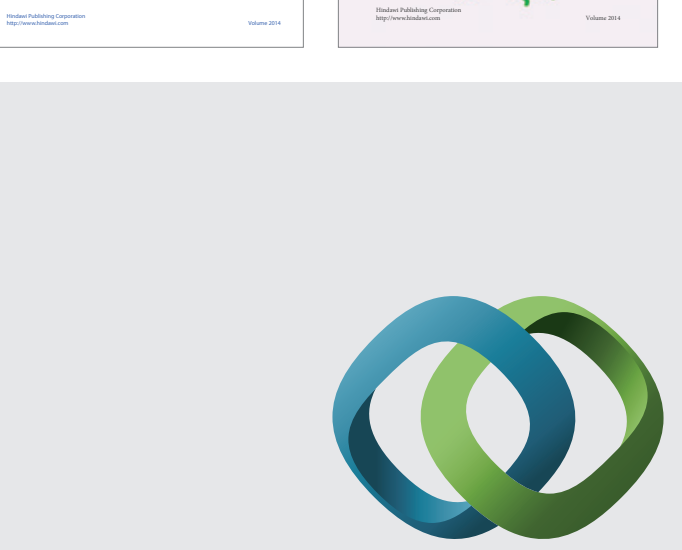

\section{Hindawi}

Submit your manuscripts at

http://www.hindawi.com
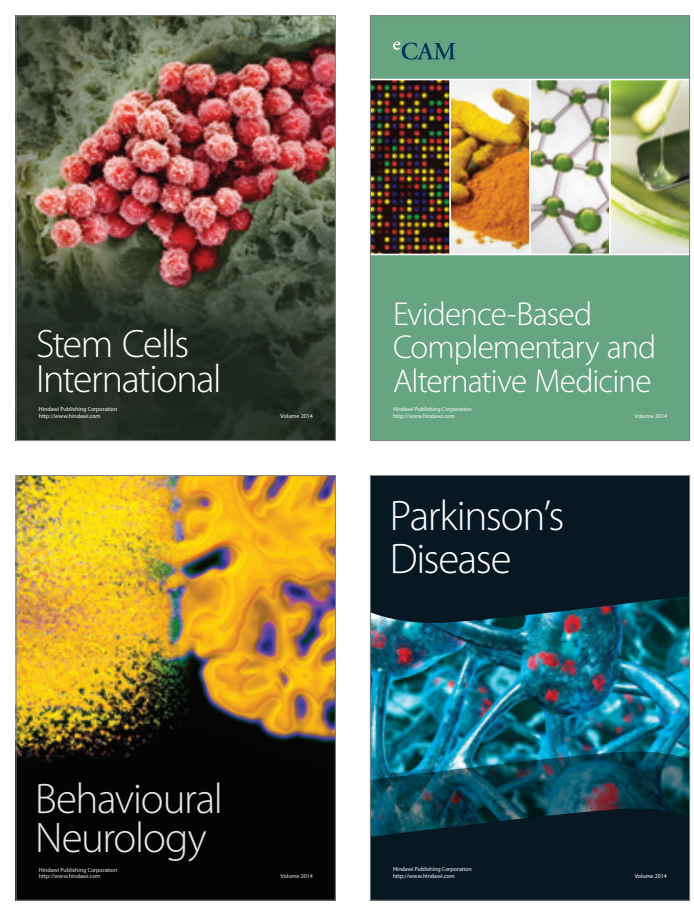

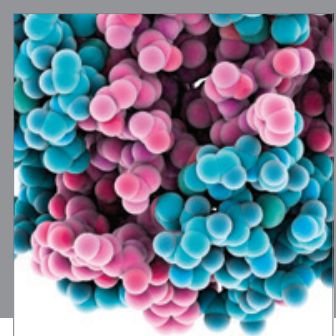

Journal of
Diabetes Research

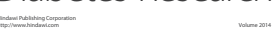

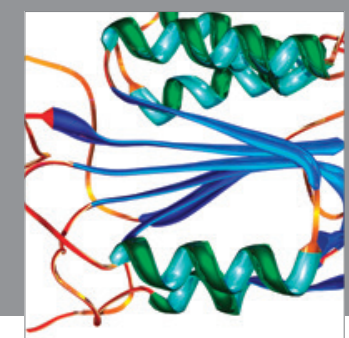

Disease Markers
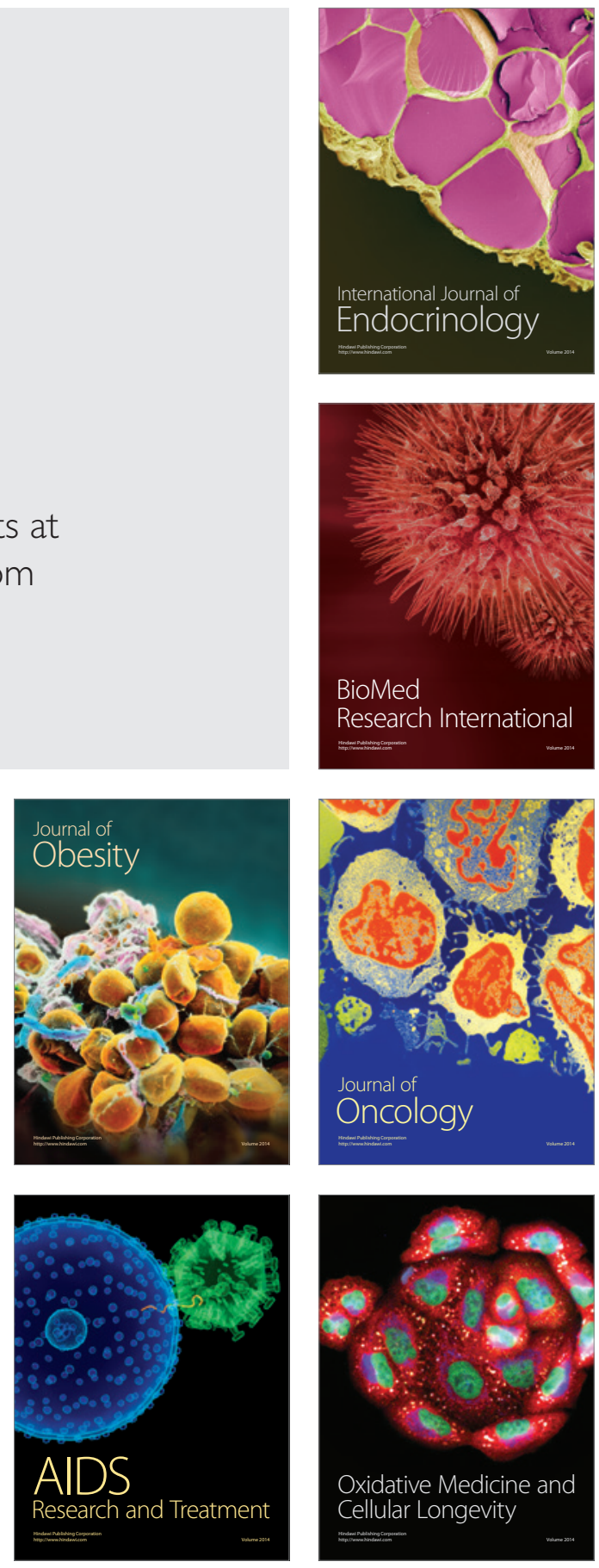